\title{
The protection of religious rights in South Africa's transitional constitution
}

\author{
Lourens M. du Plessis \\ Department of Public Law \\ University of Stellenbosch \\ STELLENBOSCH
}

\begin{abstract}
This article explains in outline how religious rights and freedoms are protected in South Africa's transitional constitution. It not only deals with these rights and freedoms as such, but also with related rights and freedoms which amplify and enhance constitutional entitlements in the religious sphere. The operation of section 14 of the constitution (in which religious rights and freedoms are mentioned by name) and of related provisions is also discussed with reference to the operation of the bill of rights as a whole.

The freedom of religion provisions in the constitution are furthermore assessed in view of

* a clause proposed as an addendum to a Declaration on Religious Rights and Responsibilities approved and adopted by a National InterFaith Conference held under the auspices of the South African Chapter of the World Conference on Religion and Peace, and (to a lesser extent)

* certain universally accepted standards for the protection of religious rights and freedoms.

Specific articles of the Declaration on Religious Rights and Responsibilities itself are also taken into account but the declaration as a whole is not considered.
\end{abstract}

\section{Background}

The object of this contribution is to plot the parameters within which religious rights are protected in the Chapter on Fundamental Rights (chapter 3) in South Africa's transitional constitution. The freedom of religion clause (section 14) and provisions amplifying and enhancing it (see 5. below) cannot be fully understood in isolation. The genesis of chapter 3 and the hermeneutical context constituted 
by the chapter as a whole will therefore first briefly be looked at.

On only one occasion have a diversity of organised religious communities in South Africa indicated a shared preference for a specific freedom of religion clause in a bill of rights. This proposed clause was included as an addendum to the Declaration on Religious Rights and Responsibilities which was finally approved and adopted by a National Inter-Faith Conference held in Pretoria (from 22 to 24 November 1992) under the auspices of the South African Chapter of the World Conference on Religion and Peace. The freedom of religion provisions in South Africa's transitional bill of rights will be assessed in view of both this proposed clause (hereinafter referred to as the W.C.R.P.-S.A. proposed clause) and, to a lesser extent, certain universally accepted standards for the protection of religious rights and freedoms. Specific articles of the Declaration on Religious Rights and Responsibilities agreed on by the National Inter-Faith Conference will also be taken into account but the declaration as a whole will not be considered

\section{The genesis of the Chapter on Fundamental Rights}

The Negotiating Council of the Multi-Party Negotiating Process in Kempton Park appointed seven technical committees - of which the Technical Committee on Fundamental Rights during the Transition was one - to assist it in its deliberations in key areas. The Technical Committee on Fundamental Rights was informed that its first task would be to compile a limited list of fundamental rights to be entrenched during the transition. Agreeing to this list in the plenary sessions of the negotiating council turned out to be a tug of war between minimalists and optimalists which, in the end, resulted in a compromise.

The minimalists, mainly the African National Congress and its allies, argued that the list should include only those rights indispensable to the political process of transition. The optimalists, on the other hand, which were mainly parties who later withdrew from the Negotiating Process to form the Freedom Alliance, contended for the fullest possible list of rights. The South African Government-National Party alliance initially also signalled preference for the optimalist position but not at all costs.

The minimalist position coincided with the broader political view that the MultiParty Negotiating Council, as an insufficiently representative - and therefore not really legitimate - political forum, could at most agree to a transitional constitution. A more representative legislative cum constituent assembly, elected in terms of the transitional constitution, would eventually have to decide on a final constitution. The minimalists were mainly those parties and alliances believed to enjoy majority popular support. The optimalist position, on the other hand, was underpinned by a strongly held view that the Multi-Party Negotiating Council was the 
appropriate authority to decide on a final constitution which should - especially in its chapter on fundamental rights - embody the fullest possible number of absolute guarantees pertaining to a 'final' dispensation. The optimalists were parties and alliances with vested political power interests but limited popular support fearing marginalisation in a proportionally representative constitution-making process.

The Technical Committee on Fundamental Rights was mandated to identify those rights which would be 'fundamental to the transition' but was not told how long the transition was expected to last and precisely how fundamental the rights identified had to be. The technical committee, in its first progress report, listed the rights which it regarded as basic to the functioning of a democratic system of government. In its second and third progress reports it formulated criteria for the inclusion of rights in the transitional constitution. The negotiating council at no stage really approved of these criteria but agreed to the inclusion of the list of rights contained in the technical committee's third progress report.

This list of rights is, from a jurisprudential point of view, neither fatally anorectic nor satisfactorily comprehensive. Significant second generation (socio-economic) and third generation ('green' and group) rights had, for instance, not been included in the final list. The few rights in these two categories which were indeed included (with the exception of children's rights in section 30 ) enjoy but restricted protection and the sections entrenching them are also restrictively phrased.

The often conflicting ideological or 'philosophical' forces at work in the process of drafting chapter 3 can be classified with reference to two human rights traditions which have become visible in South Africa over the last fifty years, namely a libertarian and a liberationist tradition. These traditions are both 'liberal' in the sense that they share a basic commitment to a quintessence of liberal-democratic values, but they do so with a marked difference in emphasis.

The proponents of the libertarian tradition have mainly been white liberals who have expressed their opposition to authoritarian government and to apartheid in ('the old') South Africa in human rights terms. They have, however, during especially the last three years been joined by newcomers from the ranks of those who used to help uphold the apartheid regime but who have come to realise that the entrenchment of their basic rights in a libertarian vein could in future best serve their vested interests.

Ideologically the libertarian tradition draws heavily on classical (enlightenment) liberalism and contends for a bill of rights premising its value system on individual liberty (and not equality) as a core value. In respect of state authority vis à vis individual autonomy libertarians assume an abstentionist (or 'hands-off') attitude 
The liberationist tradition became South Africa's first visible human rights tradition with the adoption, in 1943, of the African National Congress document, African Claims in South Africa, followed by the Freedom Charter in 1955. In these formative documents rights sentiments are, generally speaking, expressed as a combination of political ideals and demands. The ideological underpinnings of the liberationist tradition range from social democracy to democratic socialism, with the former probably predominating at present. The liberationist tradition is, at any rate, markedly egalitarian in its basic approach.

The liberationist and libertarian traditions share a profound loyalty to a distinct core of time - honoured liberal and democratic values which includes an unquestioning deference to freedom of conscience, religion and belief. Negotiating parties, moreover, seemed to have shared the view that walls of separation between church/religion and state/politics are undesirable. All this explains why the constitutionalisation of the rights implied by these freedoms was preponderantly uncontentious. However, the right to establish educational institutions based on, amongst others, a common religion (see section 32(c) and 5.1 below) was potentially contentious since it can be exercised in such a way that it serves as a pretext for 'privatised' discrimination. This explains why its possible constitutionalisation was used as a 'bargaining chip' in bilateral discussions between the government and the ANC and why it was eventually entrenched subject to an explicit prohibition of racial discrimination (see further 5.1 below).

\section{The context of the Chapter on Fundamental Rights}

\subsection{Its style}

The provisions of the Chapter on Fundamental Rights are couched in a language reflecting preference for a particular style of formulation in which entitlements are expressed as general norms, as broadly as possible, and reliance on lists of specific and detailed guarantees and conditions have been avoided (see in general Corder et al., 1992:17-18; see also the Fifth Progress Report of the Technical Committee on Fundamental Rights par. 2). This is in stark contrast with the inflation of language characterising the traditional way of formulating statutes in South Africa using 'many words to say few things'. There are major advantages to a bill of rights using few words to say many things:

* It allows for the use of simple language which is readily accessible to the citizenry. The rights and freedoms as expressed in the bill of rights can relatively easily be understood and the formulations can become part of everyday usage instead of remaining the province of lawyers. 
* In constitutional review proceedings complicated formulations are likely to focus attention on the 'true meaning' of words and phrases rather than the really crucial question whether a right or freedom has been infringed.

* Detailed provisions containing elaborate itemisations may actually limit the protection they profess to provide as a result of the application of interpretive techniques currently used by South African courts. A judge faced with a provision containing a long list of particular items which are protected (or prohibited) may, for instance, conclude that related items which are not listed but could just as well have been included, should be taken to be excluded from the protection (or prohibition) (inclusio unius est alterius exclusio). A similar limitation of the protective effect of a bill of rights may result from the application of what have become known as the rules of restrictive interpretation

* Broadly phrased provisions allow for the evolutionary interpretation and growth of the instrument which entrenches fundamental rights and freedoms.

South African courts have thus far been essentially literalist in their approach to the interpretation of legislation (Du Plessis \& De Ville, 1993a:78-81). This approach is wholly inappropriate in interpreting a broadly phrased bill of rights and could indeed have starting consequences (see e.g. Du Plessis \& De Ville, 1993a:73-76). A 'contextually sensitive' (or holistic) and purposive approach is called for instead. 1 The wording of chapter 3 is conducive to this latter more appropriate approach.

\subsection{Its application}

Chapter 3 of the transitional constitution is introduced by a provision stating that the chapter shall bind the legislative and executive organs of the state at all levels of government (section 7(1)) which, according to the definition clause (section 232), includes all statutory bodies and functionaries. A further subsection (section 7(2)) subjects all law in force as well as all administrative decisions taken and acts performed to the provisions of the chapter for so long as it is in operation. This provision should be read with section 33(2) which states that no provision of the constitution and no rule of law (whether it be a rule of common or customary law or of legislation) shall limit any right entrenched in chapter 3 in a way other than that provided for in section 33(1) (see 3.4 below).

1 What such an approach entails, cannot be fully explained within the confines of the present article, and for a fuller exposition I can but refer to another series of articles which I coauthorcd, namcly Du Plessis \& De Ville (1993a, 1993b and 1993c). 
"Appropriate relief" can be sought when an entrenched right is infringed or threatened (section 7(4)(a)) and prospective applicants' right to approach a court on these grounds is defined extensively (section 7(4)(b)) so as to include, for instance, standing to bring an action in the interest of somebody else (section $7(4)(\mathrm{b})$ (iii)) or of a group or class of persons (section $7(4)(\mathrm{b})(\mathrm{iv})$ ) or in the public interest (section 7(4)(b)(v)).

These ostensibly unceremonious opening statements of chapter 3 read with section 4(1) which declares the constitution to be "the supreme law of the Republic", indeed herald a Copernican revolution in South African law and the legal system. For the first time in the history of this country a sovereign constitution construed and applied by the judiciary and, in particular, a specialist constitutional court ${ }^{2}$ which will hopefully be of balanced composition, will trump legislative and executive notions of what just and equitable governance entails.

Chapter 3 , in other words, forms the basis of a system of cross- and doublechecking which curbs the powers of the legislature and the executive. In concrete terms this means that any law violating a religious right or freedom can be struck down by an appropriate court of law and that any administrative act which has this effect can be undone in a similar way and its damaging consequences can, as far as possible, be repaired.

It was a matter of contention among parties participating in the Multi-Party Negotiating Process whether the provisions of chapter 3 should be enforceable against the state and its organs only or whether they should bind both the state and private social institutions and persons. In the end it was agreed that the chapter should operate vertically only ${ }^{3}$ but that provision be made for a seepage to horizontal relationships. As a result a subsection was included in the interpretation clause requiring any court of law applying and developing the existing law to have due regard to the spirit, purport and objects of the chapter (section 35(3)). To allay fears that the predominantly vertical operation of chapter 3 can be construed as authorising 'privatised apartheid', a provision was also included in the limitation clause (section 33) permitting measures designed to prohibit unfair discrimination by (private) bodies and persons not explicitly bound by the chapter (section 33(4)).

The sections in chapter 3 which entrench religious rights (and other rights amplifying and enhancing them) should therefore be understood subject to the almost

2 Provided for in sections $98-100$ of the transitional constitution.

3 Hence section 7(1) which subjects (only) the legislative and executive organs of the state to the provisions of chapter 3 - sce above. 
Lourens M. du Plessis

exclusively vertical operation of the chapter. This means that individual members of a religious community will not be able to invoke the provisions of the chapter in order to challenge rules laid down, decisions taken or acts performed by the structures of authority within their communities. The chapter mainly protects religious individuals' and communities' religious freedom against infringing laws and actions from the state (and guarantees non-religious individuals' and communities' freedom not to believe in a similar way). "The state" includes, as was pointed out at the beginning of this paragraph, the legislature and the executive at all levels of government (section $7(1)$ ) as well as statutory bodies and functionaries (section 232). This means that, for instance, local authorities, public broadcasters such as the SABC and universities are also bound by the chapter and that any conduct on their part which is allegedly discriminatory on religious grounds or which impinges on religious freedom, will be challengeable in terms of chapter 3

The seepage to horizontal relationships provided for in the interpretation clause (section 35(3)) may also affect the existing (common and statutory) law regulating the relationship between religious communities and their members. Because any court of law applying and developing the existing law is required to have due regard to the spirit, purport and objects of chapter 3 , the courts will probably interpret and apply the law regulating horizontal relationships as much as possible in conformity with the rights enshrined in the chapter. The relationship between an individual member and his or her religious community is - in so far as the member is subject to the community's structures of authority - at any rate not a purely 'horizontal' relationship. The reason for having a bill of rights as the individual's instrument of protection against the abuse of authority by the state therefore also exists (in principle) in the case of religious communities. The courts may therefore be inclined to incorporate the values enshrined in chapter 3 into the existing law dealing with the relationship between the structures of authority of a religious community and its individual members.

The previously mentioned section 33(4), which authorises measures designed to prohibit unfair discrimination by bodies and persons not referred to in section 7(1) and therefore not explicitly bound by chapter 3, makes it possible for the state to interfere with the 'private' relationship between an individual and his or her religious community in order to prevent religion from being used as a pretext for (privatised) discrimination.

\subsection{Its interpretation (and international law)}

A court of law interpreting chapter 3 is, first of all, required to "promote the values which underlie an open and democratic society based on freedom and equality" (section 35(1)). The exact implications of this value statement will have 
The protection of religious rights in South Africa's transitional constitution

to be spelt out by the South African courts (and especially the constitutional court) in due course.

Section 35(1) goes on to state that a court of law interpreting chapter 3 "shall, where applicable, have regard to public international law applicable to the protection of the rights entrenched in this Chapter, ${ }^{4}$ and may have regard to comparable foreign case law" (my italics - LMdP). The second part of this statement clearly authorises a court to consult, in its own discretion, comparable constitutional case-law of any other country and probably also of international forums, such as the European Court of Human Rights, which function on a regional basis. The first part of the statement, on the other hand, is mandatory. It stipulates that a court of law shall have regard to binding rules of international law thereby honouring South Africa's obligations under international law. South Africa is not a party to any of the more significant international human rights conventions, such as the International Covenant on Economic, Social and Cultural Rights and the International Covenant on Civil and Political Rights. Some of the norms for human rights protection enshrined in these covenants (and in the Universal Declaration of Human Rights), ${ }^{5}$ also form part of customary international human rights law binding on every state irrespective of whether it has ratified any international human rights convention or covenant (Henkin, 1985:271). Some of these norms vouch for religious freedom 6 and are part and parcel of public international law applicable to the religious rights entrenched in chapter 3 of South Africa's transitional constitution. A court of law, in interpreting those provisions of chapter 3 relating to religious freedom, is therefore required to have regard to the said norms of customary international law.

\subsection{The limitation and suspension of entrenched rights}

It is generally accepted that rights enshrined in a bill of rights are limitable. It is, however, an open question whether it is possible to limit all such rights. The right to religious freedom, for instance, entails religious practices which are surely susceptible to circumscription, but the right to freedom of conscience or belief, which is not so concretely 'exercised', lacks these readily circumscribable manifestations. On the other hand, there are certain rights which is generally believed

4 I.e. chapter 3

5 And further amplified in the U.N. General Assembly's Declaration on the Elimination of All Forms of Intolerance and of Discrimination Based on Religion and Belicf (proclaimed on 25 November 1981) - see also Ramcharan (1987).

6 For the evolution of universal standards of religious liberty, sce Ramcharan (1987) 
should not be limited, for instance the right not to be subject to torture (see section 11(2)).

Section 33(1) of South Africa's transitional constitution is a general circumscription clause providing for the limitation of all the rights entrenched in chapter 3 and therefore also the religious rights entrenched in section 14 (see 4 . below) as well as the rights amplifying and enhancing them (see 5 . below). The limitation of any right can be achieved through 'law of general application' (in other words, legal rules which apply generally and not solely to an individual case) provided that:

(i) the right in question is limited only to the extent that it is reasonable and "justifiable in an open and democratic society based on freedom and equality" (section 33(1)(a)), and

(ii) its essential content is not negated (section 33(1)(b)).

A list of illimitable rights is included in some bills of rights. Illimitability in this particularly technical sense does not, however, mean that the right in question can in actual fact not be limited at all but merely that it is not limitable by low of general application in the way described above. 'Illimitable' rights can still be limited by other rights entrenched in the bill of rights (Du Plessis \& De Ville, 1993c:385). Since chapter 3 of the transitional constitution is not a full bill of rights, it was deemed inadvisable to include a list of illimitable rights in section 33(1) because their limitation in terms of the incomplete list of rights included in the chapter itself could be ineffectual

The limitation of certain specified rights is subject to a stricter test than the one which normally applies: their limitation must, in addition to being reasonable, also be necessary (section 33(1)(aa) and (bb)). Among the rights in this category are the rights to freedom of religion, belief and opinion entrenched in section 14(1) (see section 33(1)(aa)).

Section 34 provides for strict conditions on which rights can be suspended during a state of emergency, but here all the rights entrenched in section 14 have been listed with those rights which can, even under these circumstances and on the said strict conditions, not be suspended (section 34(5)(c)).

Religious freedom is no doubt high on the priority list of basic freedoms singled out for protection in national as well as international human rights instruments Some regard it as "the most sacred of all freedoms" (Robertson, 1991:124) and it "appeared as the first fundamental human right in political instruments of both national and international character long before the idea of systematic protection of civil and political rights was developed" (Partsch, 1981:209; see also Robert- 
son, 1991:124). ${ }^{7}$ Rights which are so eminently fundamental are, in terms of international human rights standards, usually regarded as non-derogatable ${ }^{8}$ which means that they cannot be suspended even in time of a publicly proclaimed emergency when the life of the nation is threatened. ${ }^{9}$ Accordingly, article $4(2)$ of the International Covenant on Civil and Political Rights explicitly provides for the non-derogatibility of the religious rights and freedoms enshrined in article 18. The rule of non-derogatibility has probably also become part of customary international law binding on every state irrespective of whether it is a party to any international convention or covenant (Henkin, 1985:271; see also 3.3 above).

Permissible limitations furthermore seem to apply exclusively to the freedom to manifest religious beliefs and not to the freedom to hold them (Partsch, 1981:210; see also 4 below). In the same vein freedom of conscience, thought and opinion, in so far as they have not been concretely manifested, are probably also illimitable.

The limitation of religious rights could prove to be more problematic than may appear at first sight. No state could possibly permit, for example, enforced polygamy, ritual murders or public disturbance in the name of exercising religious freedom (Robertson, 1991:125): limitations on religious practices which endanger life or health or contravene public morals should, in other words, somehow be permissible (Partsch, 1981:212 n. 11 at 447)..$^{10}$ On the other hand, tyrannical regimes often profess to guarantee the free exercise of religion while, at the same time, they suppress full expression of its political and social consequences, and do so in the name of justifiably circumscribing concrete manifestations of religious freedom (Robertson, 1991:124). This happened, to a large extent, in South Africa under the apartheid regime (Robertson, 1991:126-127). The lines of de-

7 Sec c.g. the first paragraph of the Agreement of the Pcople (of England) of 28 October 1647. The First Amendment to the U.S. Constitution, which deals with religious freedom at a federal level, was proposed in 1789 (the same year in which the constitution itself came into operation) and was ratified shortly after the commencement of the constitution see Van der Vyver (1972:104).

8 With reference to section 34 of South Africa's transitional constitution 'non-derogatable' must be read as 'non-suspendable'.

9 See also Ramcharan (1985:14-17) and Gormley (1985) with regard to the non-derogatability of the right to life.

10 Partsch (1981:212), in his discussion of the protection of religious frecdom under the International Covenant on Civil and Political Rights, observes that astonishingly ample and broad limitations of the right to manifest one's religion have been admitted. He docs not, however, spell out exactly why he thinks so. 
marcation between justifiable and unjustifiable circumscriptions of religious freedom to act (see 4 below) often become blurred because

\begin{abstract}
... both religion and politics embrace in differing ways the whole of human life. Both religious movements and political movements/governments have their own view of what human beings, individually and collectively, should be. While religions stem from and work in areas of inspiration and conviction, political movements are concerned with maintaining the social and legal framework for the human community (Robertson, 1991:125). ${ }^{11}$
\end{abstract}

Chapter 3 of South Africa's transitional constitution undoubtedly conforms to internationally recognised standards for the protection of religious freedom by explicitly providing for the non-derogatability of the religious rights guaranteed in section 14. Since the limitation of these rights is subject to the stricter necessity test, the door is open for a court to conclude that the freedom to manifest religious beliefs is limitable, but that the freedom to hold them is not.

\title{
4. Religious rights in section 14
}

Section 14 of the transitional constitution provides as follows:

\section{Religion, belief and opinion}

14. (1) Every person shall have the right to freedom of conscience, religion, thought belief and opinion, which shall include academic freedom in institutions of higher learning.

(2) Without derogating from the generality of subsection (1), religious observances may be conducted at state or state-aided institutions under rules established by an appropriate authority for that purpose provided that such observances are conducted on an equitable basis and attendance at them is free and voluntary.

(3) Nothing in this Constitution shall preclude legislation recognising -

(a) personal and family law adhered to by persons professing a particular religion; and

(b) the validity of marriages concluded under a system of religious law subject to specified procedures.

11 For a deserving exposition of the interaction between (and, indecd, interdependence of) law/politics and religion, sec also Witte (1993). 
The W.C.R.P.-S.A. proposed clause (see 1. above) reads as follows:

1. All persons are entitled:

1.1 to freedom of conscience,

1.2 to profess, practise, and propagate any religion or no religion,

1.3 to change their religious allegiance.

2. Every religious community and/or member thereof shall enjoy the right:

2.1 to establish, maintain and manage religious institutions;

2.2 to have their particular system of family law recognised by the state;

2.3 to criticise and challenge all social and political structures and policies in terms of the teachings of their religion.

Section 14(1) of the transitional constitution is libertarian in its purport and there can be little doubt that it provides, in a highly individualised way, for freedom of conscience, the right to profess, practise and propagate any religion and the right to change one's religious allegiance. To this extent it is in conformity with the first subclause of the W.C.R.P.-S.A. proposed clause. Religion, however, also has an institutional dimension - as appears from 2.1 of the W.C.R.P.-S.A. proposed clause. This institutional dimension (which the W.C.R.P.-S.A. proposed clause expresses as a right "to establish, maintain and manage religious institutions") is catered for under the freedom of association clause (section 17) in the transitional constitution but it can also be argued that it is already contained in section 14(1) as it stands: religious freedom by its very nature indeed entails all rights relating to a person's involvement with a religious community. The argument that the freedoms listed in section 14(1) should be read as including the entitlement to have them institutionally expressed, is supported by the fact that academic freedom (which is one of the freedoms explicitly listed in section 14(1)) is mentioned with reference to its concretisation in institutions of higher learning. 12 It can thus be argued that on the analogy of academic freedom, the distinction between an establishment and a free exercise clause which is explicit in the First Amendment to the United States constitution (see also Van der Vyver, 1972:108),

12 Strictly 'logically' speaking the opposite can of course also be argued on an inclusio unius est alterius exclusio basis: because the institutional dimension of academic freedom is mentioned explicitly, the absence of explicit reference to the institutional dimension of religious freedom implics that, at least for purposes of section 14, the constitution-makers intended to exclude it. However, if a holistic and purposive approach to the interpretation of the bill of rights is followed (see 3.1 above) and entitlements are construcd liberally, an analogical extension of the academic frecdom formula to religious frecdom is morc appropriate than its inclusio unius restriction. Both approaches are, at any rate, equally 'logical'. See also 3.1 (iii) above. 
is implicit in the freedom of religion dimension of section 14(1). But even without such an analogy the 'establishment' aspect of section 14(1) is borne out by a holistic interpretation which relates the provisions of this section to the entrenchment (in section 17) of the right to freely associate.

The combination of religious and academic freedom in section 14(1) is unusual. The example (and, indeed, the wording) of article 21(b) of the Constitution of the Republic of Namibia was followed by the drafters of South Africa's transitional bill of rights. In the Namibian article academic freedom and the freedom to practise religion are, however, entrenched in two different sub-articles, namely articles 19(b) and (c) respectively. Because of the tug of war between the minimalists and the optimalists who were involved in multi-party negotiations (see 2 . above) the Technical Committee on Fundamental Rights refrained from explicitly referring to academic freedom in the initial drafts of chapter 3 . The committee was of the opinion that "freedom of ... thought, belief and opinion" at any rate includes academic freedom. A number of submissions were then made to the technical committee in which the explicit constitutionalisation of academic freedom and of the freedom of artistic creativity and scientific research were advocated. The technical committee recommended to the negotiating council that explicit reference be made to academic freedom in section 14(1) and to freedom of artistic creativity and scientific research in the freedom of expression clause, section 15(1). This the council accepted. Note, however, that in both instances the wording (introduced by the phrase "which shall include") suggests that the particular freedoms explicitly mentioned are at any rate included in the entitlements initially entrenched in broad and non-specific terms.

Article 5 of the Declaration on Religious Rights and Responsibilities (see 1. above) is concemed with people's enjoyment of religious rights in state institutions and it is precisely this right which section 14(2) constitutionalises. Article 5 does not, however, deal with educational institutions while section 14(2) includes them. In this sense section 14(2) to some extent supports the right to religious education elaborated on in article 4 of the declaration although section 32(c) of the transitional constitution is more to the point in this regard.

The concern raised about systems of family law in 2.2 of the W.C.R.P.-S.A. proposed clause is catered for in section 14(3) of the transitional constitution. A person's right to have his or her system of family law recognised by the state is, however, not constitutionalised. Instead the section authorises the legislature to pass legislation recognising this right. The provisional nature of section $14(3)$ is due to the fact that the question of recognising the systems of family law of religious communities was raised at a very late stage of the negotiating process and in conjunction with the highly controversial customary law issue. Although the negotiating council was amenable to the constitutional recognition of these systems, 
The protection of religious rights in South Africa's transitional constitution

it was probably well advised to proceed with circumspection. Religious groups will now have to lobby the legislature elected on 27 April 1994 to pass the necessary legislation in this regard. Section 14(3) will then safeguard such legislation against invalidation on, for instance, the ground that it favours certain persons or religious communities and is therefore discriminatory.

\section{Rights amplifying and enhancing freedom of religion}

Due to the economy of language characterising chapter 3 (see 3.1 above) religious rights and freedoms are not referred to elaborately - as is obvious from section 14. Other provisions of the chapter can, however, be construed as favouring the exercise of religious freedom thereby amplifying and enhancing the provisions of section 14. These provisions will now briefly be looked at.

\subsection{Education}

Section 32 of the transitional constitution guarantees individuals' right to basic education, to equal access to education (section.32(a)) and to instruction in a language of choice where reasonably practicable (section 32(b)). Section 32(c) then proceeds to give "every person" the right

to establish, where practicable, educational institutions based on a common culture, language or religion, provided that there shall be no discrimination on the ground of race (my italics - LMdP).

Section 32(c) adequately addresses the sentiments of religious groups articulated in articles 4.5 and 4.6 of the Declaration on Religious Rights and Responsibilities. Under the said section it will be possible for religious communities to establish and maintain their own educational institutions at pre-school, primary, secondary and tertiary levels. That these institutions will have $a$ right to financial support by the state (subject to compliance with minimum academic norms laid down by educational authorities) is, however, not a foregone conclusion (see below)

The section furthermore excludes recourse to religious freedom as a pretext for privatised racial (but not necessarily gender) discrimination. Reference has not been made to gender discrimination in order not to preclude the possibility of having religiously oriented single-sex schools.

Does section 32(c) warrant the constitutionality of a provision such as section 31 (1) of the Potchefstroomse Universiteit vir Christelike Hoër Onderwys (Private) Act (19 of 1950) which requires from the council of the university to ensure that, in appointing academic and non-academic staff, the Christian historical character of the university is maintained? At first sight it appears as if it does, but the matter is not without its complications. It is important to note that the 
university as a statutory body is bound by the provisions of chapter 3 - even though the chapter operates vertically only (see 3.2 above). If in the appointment of staff members the council of the university therefore differentiates among prospective candidates on the basis of religion, its decision could be challenged on the strength of the equality clause (section $8(1)$ and (2)) of the transitional constitution - see also 5.2 below). It could of course be argued that section 32 (c) in effect limits the provisions of the equality clause but since the principles of both freedom and equality (see e.g. sections 33(1)(a)(ii) and 35(1) of the transitional constitution) guide the interpretation and application of chapter 3 (see 3.2 above), this limitation has to be construed restrictively. The council of the university could therefore act unconstitutionally if it were to exclude someone from appointment simply because his or her religion does not conform to the 'Christian historical character of the university'. An atheist unlikely to undermine the said character will, for example, not only be eligible for appointment but could indeed challenge a decision of the council excluding him or her from appointment mainly on the basis of his or her atheistic beliefs.

Of more significance still are the standards laid down in article 13(3) of the International Covenant on Economic, Social and Cultural Rights. This article guarantees the right of parents to "ensure the religious and moral education of their children in conformity with their own convictions" but at the same time it states that this right can be exercised by parents choosing "schools ... other than those established by the public authorities". From this follows that "[ $t]$ he state is not obliged to finance such education but only to tolerate it if the parents wish to provide for it or pay for it" (Partsch, 1981:213). Thus, even if it could be argued that the article 13(3) standards apply to tertiary education as well, it seems as though a future South African government will not be out of step with international human rights standards should it recognise the right of the Potchefstroom University for Christian Higher Education to maintain its 'Christian historical character' without, however, supporting the institution financially. On the other hand, the mere fact that the right to establish an educational institution on the basis of a common religion is regarded as of sufficient significance to constitutionalise it in explicit terms, could serve as a basis for an argument that the state is under an obligation to provide financially for such an institution. No South African university will at any rate be able to survive without financial support from the state

\subsection{Equality}

Article 2 of the Declaration on Religious Rights and Responsibilities is adamant in proclaiming the equality before the law of religious communities. Section 8 of the transitional constitution is equally adamant in proclaiming every person's "equality before the law and ... equal protection of the law" (section $8(1)$ ) in pur- 
The protection of religious rights in South Africa's transitional constitution

suance of which discrimination on the grounds of (amongst others) religion, conscience or belief are precluded (section $8(2)$ )

Ironically, however, the voluminous (and apprehensive) submissions on the equality provision in the transitional constitution which came from spokespersons of religious communities did not address the entrenchment of religious equality but rather the stipulation (in section $8(2)$ ) that "no person shall be unfairly discriminated against" on the ground of "sexual orientation".

\subsection{Expression, association, language and culture}

The freedom of expression clause in the transitional constitution (section 15(1)) certainly caters for the need of religious communities to "criticise and challenge all social and political structures and policies in terms of the teachings of their religion" (see 2.3 of the W.C.R.P.-S.A. proposed clause). The transitional constitution (section 15(2)) moreover provides that "media financed by or under the control of the state shall be regulated in a manner which ensures impartiality and the expression of a diversity of opinion". This goes a long way in addressing religious communities' concern about having "reasonable access to ... publiclyowned communications media" (article 7 of the Declaration on Religious Rights and Responsibilities).

As was pointed out previously, the freedom of association clause in the transitional constitution (section 17) enhances the institutionalised exercise of religious freedom - as does section 31 (on language and cultural rights) for religious communities to whom the exercise of their religious freedom is closely related to or dependent on language and culture.

\subsection{Access to court and administrative justice}

Members of religious communities, like all other bodies and persons, "shall have the right to have justiciable disputes settled by a court of law or, where appropriate, another iudependent and impartial forum" (section 22). This means that members of a religious community can (as of right) have recourse to either a court of law or 'an outside referee' should they not be able to resolve their disputes among themselves. Strictly speaking, the section in the transitional constitution on administrative justice (section 24) does not bind religious communities, since the chapter on fundamental rights operates vertically only (see 3.2 above). However, the requirement that religious communities should comply with the precepts of natural justice in instances where the rights of any of their members stand to be affected by decisions, forms part of the law as it stands. The provision in the transitional constitution allowing for a seepage of the provisions of chapter 3 to horizontal relationships (section 35(3)) could therefore well be taken as reinforc- 
ing the right of any member of a religious community to the application of (what in legal nomenclature is known as) the rules of natural justice in instances where disputes between the member and the religious community concerned are to be resolved. These rules require that both sides to a dispute be heard (audi et alteram partem) and that no person involved in the dispute can be judge in his or her own cause (nemo iudex in re sua). ${ }^{13}$

\section{Concluding perspective}

Chapter 3 of the transitional constitution provides a broad framework within which religious rights and freedoms (and rights relating to them) are entrenched. It is now for religious communities themselves to spell out exactly what the actualisation of these rights and freedoms means in practice. The W.C.R.P.-S.A. Declaration on Religious Rights and Responsibilities is a noteworthy starting point in this regard. The courts (and especially the constitutional court) could well consult declarations or charters of this nature in order to give content to the religious (and related) rights and freedoms entrenched in broad terms in the bill of rights.

Religious communities are also under an obligation to make their members aware of their rights and of the implications of the entrenchment of those rights in chapter 3. Rights are worth nothing if they are simply listed in and elaborated on in lofty statements. They are there to be used in order to help optimalise the fulfilment of one's calling in all the various spheres of life. This holds, in particular, for the rights of religious people and communities.

\section{Bibliography}

CORDER, HUGH; KAHANOVITZ, STEVE; MURPHY, JOHN; MURRAY, CHRISTINA; O'REGAN, KATE; SARKIN, JEREMY; SMITH, HENK \& STEYTLER, NICO 1992. A Charter for Social Justice: A Contribution to the South African Bill of Rights Debate. Cape Town : Department of Public Law U.C.T

DU PLESSIS, LOURENS M. \& DE VILLE, J.R. 1993a. Bill of Rights Interpretation in the South African Context (1): Diagnostic Observations. Stellenbosch Law Review, 4(1):6387.

DU PLESSIS, LOURENS M. \& DE VILLE, J.R. 1993b. Bill of Rights Interpretation in the South African Context (2): Prognostic Observations. Stellenbosch Low Review, 4(2): 199-218

13 Adjudication in the context of religious communities is at any rate fraught with problems, as Van der Vyver (1986:183-187) clearly shows. Only time will learn whether the introduction of chapter 3 will add to or help solve these problems 
The protection of religious rights in South Africa's transitional constitution

DU PLESSIS, LOURENS M. \& DE VILLE, J.R 1993c Bill of Rights Interpretation in the South African Context (3): Comparative Perspectives and Future Prospects. Stellenbosch Law Review, 4(3):356-393.

GORMLEY, W.P. 1985. The Right to Life and the Rule of Non-gerogatability: Peremptory Norms of Jus Gogens. (In Ramcharan, B.G. ed. The Right to Life in International Law. Dordrecht/Boston/Lancaster : Martinus Nijhoff. p. 120-159.)

HENKIN, LOUIS 1985. Human Rights. (In Encyclopedia of Public International Law VIII Amsterdam/New York/Oxford : North-Holland. 268-274.)

MULTI-PARTY NEGOTIATING PROCESS. Progress Reports of the Technical Committee on Fundamental Rights during the Transition.

PARTSCH, KARL JOSEF 1981. Freedom of Conscience and Expression, and Political Freedom. (In Henkin, Louis ed. The International Bill of Rights: The Covenant on Civil and Political Rights. New York : Columbia University Press. p. 207-245.)

RAMCHARAN, B.G. 1985. The Concept and Dimensions of the Right to Life. (In Ramcharan, B.G. ed. The Right to Life in International Law. Dordrecht/Boston/Lancaster : Martinus Nijhoff. p. 1-32.)

RAMCHARAN, BERTIE 1987. Towards a Universal Standard of Religious Liberty. (In Religious Liberty. Commission of the Churches on International Affairs : World Council of Churches. p. 8-13.)

ROBERTSON, MIKE ed. 1991. Human Rights for South Africans. Cape Town : Oxford University Press.

VAN DER VYVER, J.D. 1972. Die juridiese funksie van staat en kerk. Durban : Butterworths.

VAN DER VYVER, J.D. 1986. Religion. (In Joubert, W.A. \& Scott, T.J. eds. The Law of South Africa. Vol 23. Durban/Pretoria : Butterworths. p. 175-202.)

WITTE, JOHN 1993. Towards an Integration of Law and Religion. Pretoria : University of Pretoria : The Centre for Human Rights. 